\title{
Geological setting and depositional environment of the Stirling Group of southeastern Cape Breton Island, Nova Scotia
}

\author{
Alan S. Macdonald and Sandra M. Barr \\ Department of Geology, Acadia University, Wolfville, Nova Scotia BOP 1XO, Canada
}

Date Received March 9, 1993

Date Accepted August 30, 1993

\begin{abstract}
The Stirling Group consists of ca. $680 \mathrm{Ma}$ volcanic and volcaniclastic rocks, interpreted to have been deposited in and around a trough flanked by felsic volcanic centres. The volcaniclastic rocks are dominated by lapilli tuff and tuffaceous litharenite sequences. The lapilli tuffs show some evidence of subaqueous reworking but most may have originated as air-fall deposits. Sedimentary structures in the litharenites suggest subaqueous mass transport into the trough and deposition below wave base. Pyritic siltstone-chert-carbonate laminites, which are locally associated with the litharenites along the southeastern side of the trough adjacent to felsic volcanic centres, probably represent a mixture of fine-grained distal turbidites and chemical precipitates from subaqueous volcanic exhalations. The volcanic rocks of the Stirling Group do not show convincing evidence for subaqueous deposition: the felsic rocks appear to form subvolcanic intrusions and domes flanked by felsic crystal-rich lapilli tuff and rare welded(?) tuff; the mafic volcanic rocks are not pillowed but are closely associated with breccias which may have formed partly by quench fragmentation. The overall facies assemblage and its association with VMS $\mathrm{Zn}-\mathrm{Pb}-\mathrm{Cu}-\mathrm{Ag}-\mathrm{Au}$ mineralization are compatible with generation in an intra-arc basin. As the Stirling Group is significantly older than the volcanic belts which flank it, it may represent a tectonically displaced remnant of a pre-existing arc.
\end{abstract}

Le Groupe de Stirling consiste en roches volcaniques et volcanoclastiques d'environ $680 \mathrm{Ma}$, interprétées comme ayant été déposées à l'intérieur et autour d'une fosse bordée de centres volcaniques felsiques. Les roches volcanoclastiques sont dominées par des séquences de tufs à lapilli et de litharénites tuffacées. Les tufs à lapilli montrent quelques évidences de remaniement subaqueux mais la plupart pourraient être des dépôts de retombées aériennes. Les structures sédimentaires dans les litharénites suggèrent des mouvements de masse subaqueux dans la fosse et une déposition sous la base des vagues. Des laminites de siltstone pyriteux, chert et carbonates, qui sont localement associées aux litharénites le long du flanc sud-est de la fosse à proximité des centres volcaniques felsiques, représentent probablement un mélange de turbidites distales à grain fin et de précipités chimiques provenant d'éxhalaisons volcaniques sous-marines. Les roches volcaniques du Groupe de Stirling ne montrent pas d'évidences convaincantes de dépôt sous-marin: les roches felsiques semblent former des intrusions subvolcaniques et des dômes bordés de tufs à lapilli felsiques riches en cristaux et de rares tufs soudés (?); les roches volcaniques mafiques ne sont pas coussinées mais sont étroitement associées à des brèches qui ont pu en partie se former par fragmentation reliée à la trempe. L'assemblage général de faciès et son association avec de la minéralisation en sulfures massifs volcanogènes de $\mathrm{Zn}-\mathrm{Pb}$ - $\mathrm{Cu}$ - $\mathrm{Ag}$ - $\mathrm{Au}$ sont compatibles avec une formation dans un bassin intra-arc. Comme le Groupe de Stirling est nettement plus ancien que les ceintures volcaniques qui le bordent, il pourrait représenter un vestige d'un arc préexistant déplacé tectoniquement.

[Traduit par la rédaction]

\section{INTRODUCTION}

The geology of southeastern Cape Breton Island is dominated by the Stirling, Coastal, and East Bay Hills belts (Fig. 1), composed of volcanic and volcaniclastic low-grade metamorphic rocks and associated granitoid plutons of Late Precambrian age. The belts are separated from each other partly by Cambrian and Carboniferous clastic sedimentary cover sequences, and partly by major faults. They are generally considered to be typical of the Avalon Zone or Terrane of the northern Appalachian Orogen (Williams, 1979; O'Brien et al., 1983; Barr et al., 1990; Keppie and Dostal, 1991). The Stirling belt, located in the south-central part of the region, is of special interest because it hosts massive sulphide mineralization (the abandoned Mindamar $\mathrm{Zn}-\mathrm{Pb}-\mathrm{Cu}-\mathrm{Ag}-\mathrm{Au}$ deposit) and has been the focus of repeated exploration efforts for over three decades. However, until the present study, no complete description of the rock units of the belt nor any map of their distribution had been published since the initial study of Weeks (1954).

The volcanic and sedimentary rocks of the Stirling belt, which lack fossils, were assigned by Weeks (1954) to the Bourinot Group of Cambrian age on the basis of lithological correlation with volcanic and associated fossiliferous strata in the Boisdale Hills of central Cape Breton Island. However, recognizing that the Stirling rocks are unconformably overlain by Lower to Middle Cambrian strata southwest of the Mira River, Smith (1978) and Keppie (1979) correlated them with the Upper Precambrian Fourchu Group of the Coastal belt to the southeast and the East Bay Hills belt to the northwest (Fig. 1). Subsequent mapping and radiometric dating throughout southeastern Cape Breton Island (Barr et 


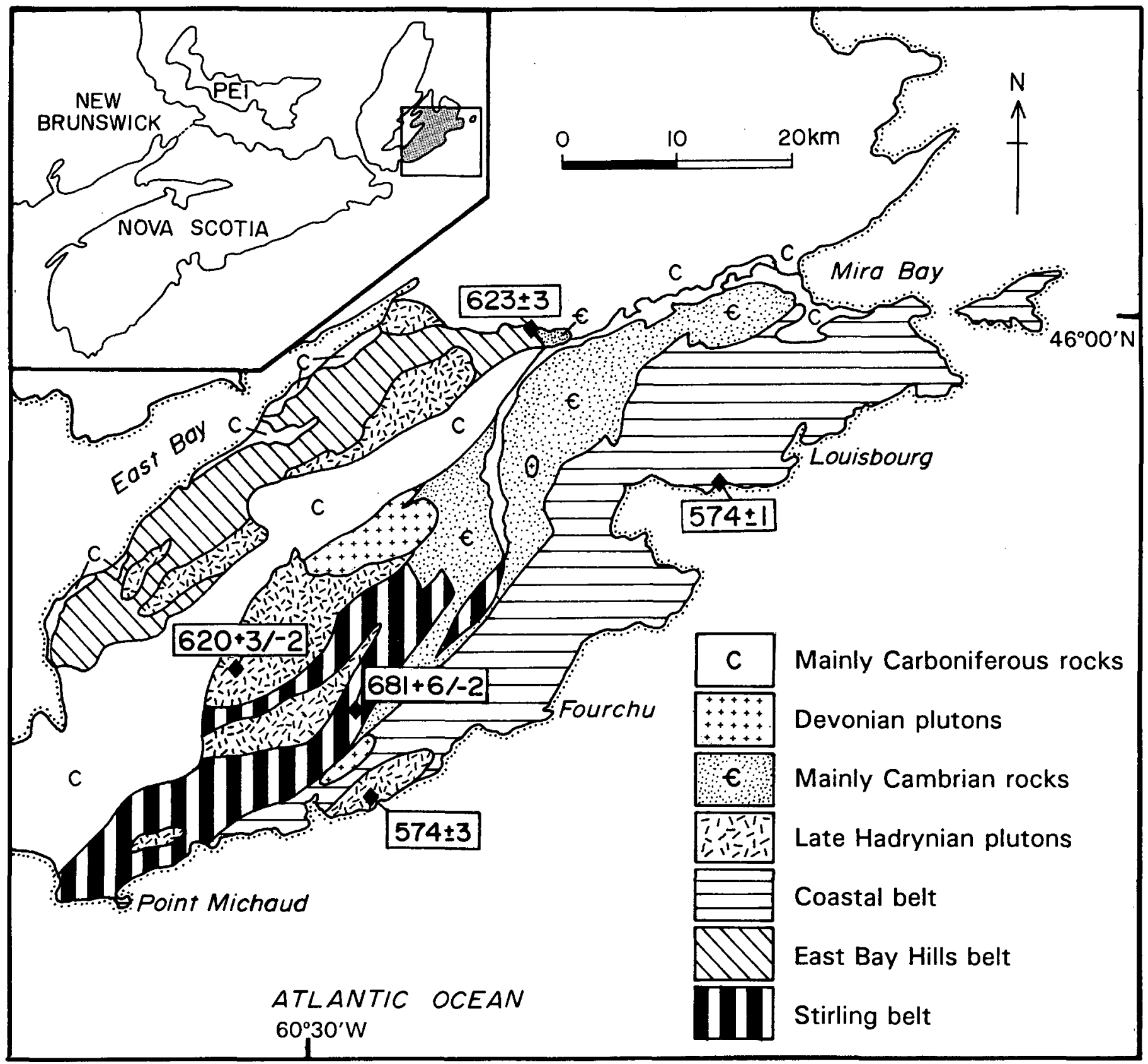

Fig. 1. Generalized geological map of southeastern Cape Breton Island showing the location of the Stirling belt and U-Pb zircon ages (after Bevier et al., 1993). Inset map shows map area (shaded). CBI = Cape Breton Island; PEI = Prince Edward Island.

al., 1988, 1989; Bevier et al., 1993) showed that the volcanic and sedimentary rocks of the Stirling belt differ lithologically from, and are also significantly older than, those of the East Bay Hills and Coastal belts. For these reasons, volcanic and sedimentary rocks of the Stirling belt have been formally named the Stirling Group in order to distinguish them from the re-defined Fourchu Group to the southeast and from the newly named East Bay Hills Group to the northwest (Barr et al., in press).

Although there appears to be general agreement that the rocks of the Stirling belt were formed in a volcanic arc setting, the volcanic rocks display significant geochemical variations which have been interpreted in different ways. The mafic flows, in particular, have been classified as (i) tholeiitic transitional to calc-alkalic basalts (Dostal et al., 1990), (ii) island arc tholeiites (Doyon and Van Wagoner, 1991; $M$. Doyon, personal communication, 1992), and (iii) as altered calc-alkalic basalts (Barr et al., in press; Barr, in press). Some of the variation is probably due to the effects of widespread very low-grade metamorphism (Dostal et al., 1990, 1992; Barr et al., in press) and perhaps also to more restricted hydrothermal alteration, but some may also be due to the difficulties of distinguishing flows from intrusive sheets in many of the poor inland exposures and of establishing their ages (M. Doyon, personal communication, 1992, 1993).

Given the ambiguity of the chemical data as to the precise chemical affinity and tectonic setting of the volcanic rocks of the Stirling Group, the purpose of this paper is to 
describe and interpret the depositional and structural features of the various lithofacies of the group and hence speculate as to the geological setting in which the belt was formed.

\section{General Geology}

\section{Overview}

The Stirling Group is dominated by andesitic to basaltic lapilli tuff and tuffaceous sedimentary sequences. Subordinate units include basaltic flows and breccias, rhyolitic crystal-rich lapilli tuff, and rhyolite porphyry (Fig. 2). Intrusive sheets of porphyritic basalt and gabbro are also common in most units. All of these rocks have been affected by very lowgrade to low-grade metamorphism and by compressive and shear deformations of varied intensities.

Granitoid rocks which have intruded the group include large dioritic to granitic plutons of the Chisholm Brook Suite of Late Hadrynian age, albitized leucogranite of the Grand River pluton, probably also of Late Hadrynian age, and the Salmon River rhyolite porphyry and associated small monzodiorite bodies of probable Devonian age (Barr et al., in press; Barr and Macdonald, 1992).

Based on mapping and petrological studies, the Stirling Group is subdivided into seven map-scale lithofacies units (Fig. 2), which are described below sequentially from southeast to northwest across the belt. Stratigraphic relations are uncertain due to poor inland exposures, and to the possibility of undetected lateral facies changes, and volcanic or structural repetitions.

The age of the Stirling Group is given by a U-Pb zircon date of $681+6 /-2 \mathrm{Ma}$ (Bevier et al., 1993) from rhyolite porphyry in the eastern part of the group (Fig. 1). However, because of the uncertainty in stratigraphic relations, it is important also to note that a minimum age for the western part of the group is provided by ca. $620 \mathrm{Ma} \mathrm{U}-\mathrm{Pb}$ and ${ }^{40} \mathrm{Ar} /{ }^{39} \mathrm{Ar}$ hornblende dates from granodioritic and dioritic plutons of the Chisholm Brook Suite (Barr et al., 1990; Keppie et al., 1990).

A possible correlative of the Stirling Group can be found in the Avalon Terrane of southeastern Newfoundland in the Connaigre Bay Group, a sequence of subaerial volcanic and interbedded sedimentary rocks which also hosts massive sulphide mineralization and has yielded a U-Pb age of ca. 680 Ma (Swinden and Hunt, 1991).

\section{Lithofacies units}

(i) Quartz-feldspar rhyolite porphyry forms elongate bodies along the southeastern side of the belt, extending from Stirling southwest to St. Esprit where they are cut out by the L'Archeveque - Mira Bay fault system (Fig. 2). Near Stirling, the porphyry forms small satellitic domes which are flanked by tuffaceous litharenite and laminated siltstone. These may represent emergent domes but the more strongly porphyritic and homogeneous nature of the largest body suggests that it may be of subvolcanic origin. The porphyry is composed of relatively uniform rhyolite to rhyodacite which varies from pale grey to green or buff depending on the type and intensity of alteration (typically either chloritic or calcareous). Phenocrysts of embayed quartz, albite, and K-feldspar make up 30 to $40 \%$ of the rock and vary in size from about 2 to $7 \mathrm{~mm}$. These are set in a fine-grained quartzofeldspathic matrix with variable amounts of sericite, chlorite, epidote, and calcite. Locally developed foliation, defined by aligned sericite and chlorite enclosing strained and fractured phenocrysts, marks mylonitic shear zones within the porphyry, some of which are occupied by quartz-carbonate schist lenses.

The Mindamar volcanic-exhalative $\mathrm{Zn}-\mathrm{Pb}-\mathrm{Cu}-\mathrm{Ag}-\mathrm{Au}$ deposit occurs in what appears to be a stratigraphically controlled position between sheared rhyolite porphyry and quartz-carbonate rock, and overlying tuffaceous sedimentary rocks (Miller, 1979).

(ii) Several bodies of porphyroclastic felsic schist locally flank the massive rhyolite porphyry unit. The schists are pale grey to grey-green or buff, and appear to have been formed largely from quartz and feldspar crystal-rich lapilli tuffs, but may include some thin rhyolite flows. They contain from 5 to $50 \%$ angular to subrounded rhyolite and lesser dacite fragments, and abundant quartz and altered feldspar porphyroclasts in a foliated matrix of sericite, chlorite, epidote and calcite. These rocks are assumed to represent tuffs which formed part of the volcanic edifice above/around the more massive rhyolite porphyry.

(iii) Overlying, and partly interbedded with the rhyolitic rocks, is a composite unit, at least $1500 \mathrm{~m}$ thick, which consists mainly of varied, grey to green or purple lapilli tuffs interbedded with less abundant ash tuffs of broadly andesitic composition. The lapilli tuffs generally occur in massive to normally graded layers and typically contain lithic fragments of dacite, andesite and(or) basalt up to about $5 \mathrm{~cm}$ in size and subangular in shape, although rare well-rounded clasts are also present. The ash tuff layers are up to several metres thick and composed of fine-grained plagioclase, quartz, chlorite, and calcite. They typically display phyllitic fabrics due to abundant chlorite. Also present in the unit are layers of coarse-grained pyroclastic breccia, tuffaceous conglomerate and litharenite, and rare welded(?) dacitic lapilli tuff. Intrusive sheets of variably porphyritic basalt, typically $15 \mathrm{~cm}$ to $2 \mathrm{~m}$ in thickness, are a common feature of many outcrops, and several large, map-scale bodies of basalt porphyry and gabbro also intruded the unit. The unit is interpreted to consist dominantly of pyroclastic fallout deposits which underwent some subaqueous reworking to produce the associated tuffaceous clastic sediments.

(iv) A predominantly tuffaceous sedimentary unit interfingers with and overlies the composite lapilli tuff unit. It occurs mainly along the central part of the Stirling belt (interrupted by plutonic rocks) and also discontinuously along the southeastern margin of the belt near Point Michaud, L'Archeveque and Stirling (Fig. 2). 


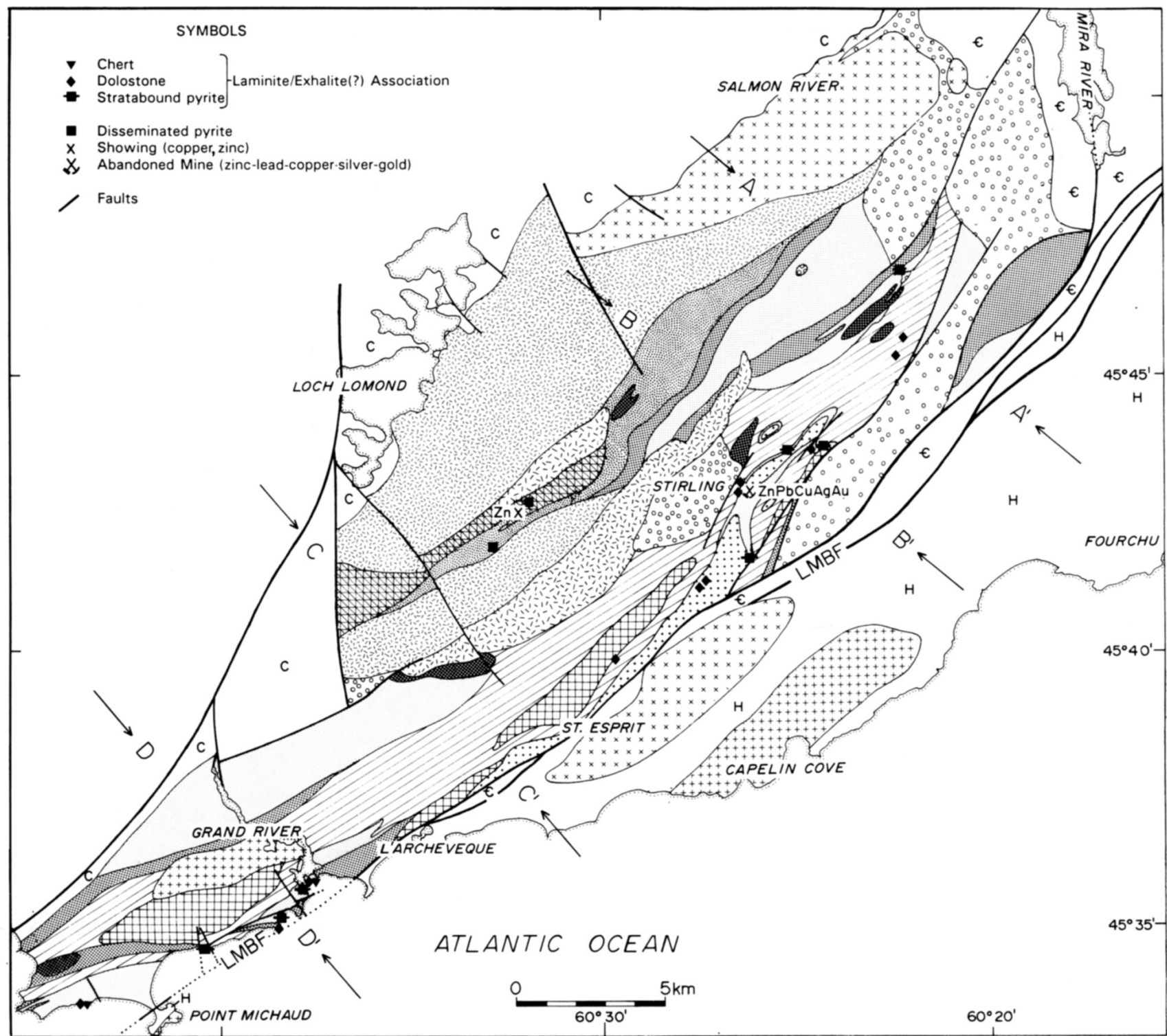

DEVONIAN

INTRUSIVE ROCKS

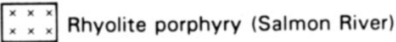
(St. Esprit)

LATE HADRYNIAN

Leucogranit Granodiorite

Diorite \& quartz diorite

Gabbro \& basalt porphyry

STRATIFIED ROCKS

\section{CARBONIFEROUS}

C Horton Group and overlying units

CAMBRIAN

$€$ Sgadan Lake \& younger formations LATE HADRYNIAN - EARLY CAMBRIAN

$\because$ Kelvin Glen Group

LATE HADRYNIAN

FOURCHU GROUP (Coastal belt)

H Mainly volcanic and volcaniclastic rocks

STIRLING GROUP

Rhyolite flows(?) \& lapilli tuffs, minor andesitic tutf

Basalt-andesite-dacite flow breccias

Basalt-andesite flows, flow breccias, minor lapilli tuff Litharenite, conglomerate, siltstone-chert-dolostone laminites Andesitic lapilli tuff \& ash tuff, minor dacite Mainly rhyolitic lapilli tuff (variably mylonitized) Rhyolite porphyry

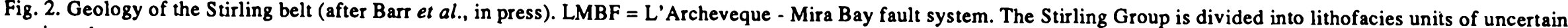
stratigraphy. 
The central tract, which is estimated to be 700 to $800 \mathrm{~m}$ thick, consists of thickly bedded, graded, grey to grey-green tuffaceous litharenite, interbedded with conglomerate and minor laminated siltstone. Subordinate lithologies include andesitic lapilli tuff and pyroclastic breccia, together with restricted occurrences of grey quartz-rich sublitharenite and laminated red and grey siltstone.

The southeastern tract consists of coarse tuffaceous litharenite, feldspathic litharenite, and rhythmically interbedded laminated siltstone, chert, and rare micritic dolostone. Compared to the central tract, the unit in this southeastern area is generally thinner (probably not exceeding about $200 \mathrm{~m}$ in thickness) and finer grained, mainly lacks conglomerate, and has a higher proportion of interbedded laminated rocks, all suggestive of a more distal depositional environment.

Typical litharenite in both tracts consists of subangular to subrounded plagioclase and less abundant quartz grains, with small clasts of basaltic to dacitic volcanic rocks, siltstone, and arenite set in a fine-grained matrix of chlorite, calcite, feldspar, and quartz. Sedimentary structures in the litharenites include ubiquitous graded bedding, basal scours and ripup siltstone clasts, and, less commonly, cross bedding. The conglomerate layers contain matrix-supported, subangular to well-rounded andesite and dacite pebbles and cobbles up to $10 \mathrm{~cm}$ across. The laminated siltstone is characterized by parallel laminations, small-scale grading, loadcasts, and slump folds; cross laminations and wavy laminations are very rare. Stratabound concentrations of fine-grained pyrite, as framboids and cubes, are also a distinctive feature of some of the laminated siltstone sequences, particularly in coastal exposures south of Grand River, and in the river and stream sections north and south of Stirling (Fig. 2). The chert and dolostone layers that occur interbedded with the laminated siltstone in the southeastern tract of the unit are generally a few millimetres to centimetres in thickness, although thicker layers of dolostone up to several metres thick occur in the Middle Framboise River north-northeast of Stirling (Fig. 2). The dolostone commonly weathers to a distinctive dark orange colour.

Coastal exposures of the tuffaceous sedimentary unit north-northeast of Point Michaud locally include lenses of polymictic roundstone conglomerate and pebbly subarkose, apparently interbedded with tuffaceous litharenite, siltstone laminite, and basaltic lapilli tuff. Clasts in the conglomerate include leucogranite, rhyolite, dacite and minor grey quartzite, and indicate a provenance different from that of conglomerates in the central tract of the unit.

(v) Basaltic rocks commonly flank the litharenite-conglomerate-siltstone unit and are to some extent interbedded with it and with the adjacent andesitic tuff unit (Fig. 2). More than one basaltic unit is probably present and structural repetition due to large-scale folding is also likely (Fig. 3). The basaltic units consist mainly of fine-grained amygdaloidal to subporphyritic basalt, basaltic flow breccia and basaltic lapilli tuff; sheets and composite dykes of porphyritic basalt are also common. The basalts, which are typically dark green in colour and patchily epidotized, contain variably altered plagioclase $\left(A n_{12.17}\right)$, chlorite, epidote, sphene, opaque minerals, calcite, and rare relict clinopyroxene. Primary igneous textures have generally survived and are mainly fine-grained pilotaxitic to intergranular. Amygdales and veins contain quartz, calcite, chlorite, epidote, prehnite, zeolites(?), and rare pumpellyite.

In the southern part of the belt, the basaltic unit is well exposed in coastal sections north of Point Michaud where the flows grade into basaltic breccias, and are also interlayered with heterolithic basaltic to andesitic lapilli tuff, and locally with pyritic siltstone. The breccias, which contain both vesicular and massive, generally angular fragments cemented by fine-grained volcanic material, calcite, and hematite, are interpreted to be autoclastic flow breccias. Inland, the basaltic units are poorly exposed, and their extent and boundaries are inferred from sparse outcrops and from magnetic data (Geological Survey of Canada, 1977).

(vi) In the northwestern part of the Stirling belt, the basaltic unit grades into a laterally equivalent or possibly underlying, thick sequence of grey-green to dark green, or black volcanic breccias, with subordinate mafic sheets and flows(?). Basaltic to andesitic varieties predominate but dacitic breccias are also present. The fragments are angular in shape, are cemented by fine-grained volcanic material of the same composition, and generally range in size from 1 to $3 \mathrm{~cm}$, but coarser varieties with fragments up to $10 \mathrm{~cm}$ occur locally. The angular shape of the fragments, their jigsaw-fit textures, and minimal vesicularity suggest the possibility that they may have been formed as hyaloclastites by in situ quench fragmentation (Cas, 1992). Near granodiorite and diorite of the Chisholm Brook Suite, the breccias and any associated massive sheets/flows have been extensively hornfelsed and commonly contain actinolite and biotite, in addition to albite, chlorite, epidote and sphene.

(vii) Toward the southwest along strike, the breccia unit is replaced by a poorly exposed felsic unit which consists mainly of pale greenish aphanitic to grey-green fine-grained rhyolite with subordinate interbedded felsic and mafic lithic lapilli tuff. This unit is flanked by granodiorite and diorite of the Chisholm Brook Suite and has been extensively contact metamorphosed and locally mineralized (Fig. 2).

\section{Mafic intrusions}

Basalt porphyry and coarser, more equigranular gabbro form several map-scale sheets or small plutons which have intruded various units of the Stirling Group (Fig. 2). Typically, they are very altered and are composed of plagioclase (variably altered to chlorite-sericite-epidote), amphibole, chlorite, epidote, and calcite; relict clinopyroxene survives only rarely. Given their altered nature, it is possible that these large mafic intrusions are the same age as the many smaller, altered porphyritic basalt sheets and composite dykes which have extensively intruded the mafic flows and breccias, and 


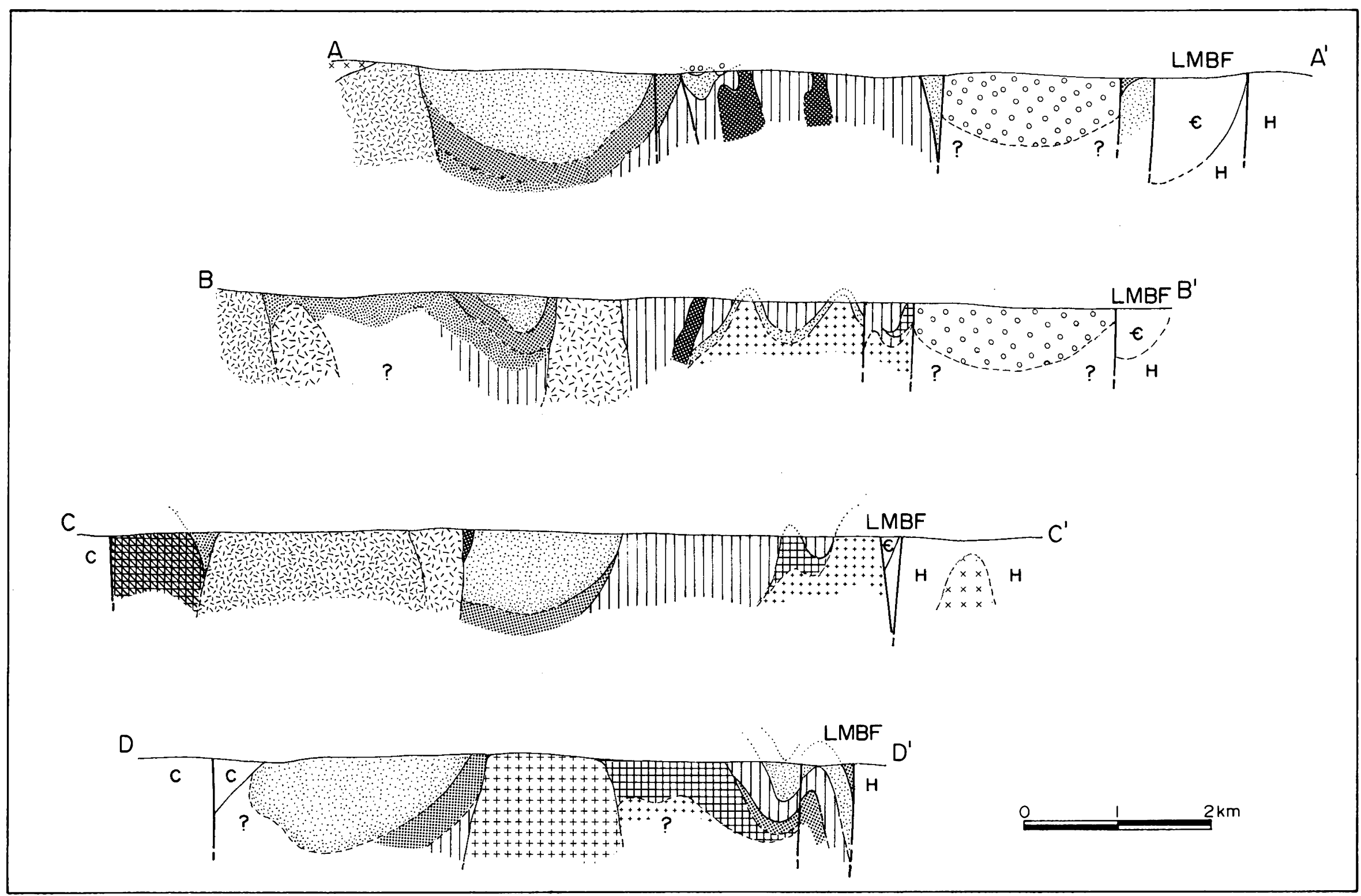
sections are indicated on Figure 2. Legend is the same as for Figure 2. 
other units of the Stirling Group. The age(s) of these intrusions is problematic: they have been considered to be either synvolcanic (Dostal et al., 1990) or post-volcanic (Miller, 1979). As many small mafic bodies also intruded the ca. 620 Ma Chisholm Brook Suite, the ca. $575 \mathrm{Ma}$ Coastal belt, and Cambrian rocks northeast of the Stirling Group (Barr et al., in press), some or all of the intrusions in the Stirling Group could be significantly younger than the volcanism, and of varied ages.

\section{Structural Geology}

The volcanic and volcaniclastic rocks of the Stirling belt display inhomogeneous patterns of deformation, which probably reflect the influence of a variety of factors, including (i) primary volcanic architecture, (ii) strong ductility contrasts during deformation among the various lithological units and subunits, (iii) development of mylonitic shear zones, and (iv) proximity to the L'Archeveque - Mira Bay strike-slip fault system.

Basaltic flows, breccias, and associated lapilli tuffs in the Point Michaud - L'Archeveque area are generally weakly to moderately foliated $\left(S_{1}\right)$ but with locally superimposed, more strongly foliated shear zones $\left(S_{2}\right)$ up to a few metres in width. In contrast, rocks of similar lithologies that occur northwest of Stirling appear virtually unfoliated, although this is in part due to extensive contact metamorphism by granitoid plutons of the Chisholm Brook Suite.

Among the felsic rocks, rhyolite porphyry is generally massive but where sheared it is easily confused with rhyolitic crystal-rich lapilli tuffs, which generally display a moderate to strong pervasive mylonitic foliation $\left(\mathrm{S}_{2}\right.$ ?) giving them a phyllitic to schistose appearance.

The tuffaceous litharenite and more especially the laminated siltstone-chert-dolostone sequences commonly display small and large-scale upright $F_{1}$ folds which plunge at about $30^{\circ}$ east-northeast to north-northeast. A widely spaced to weak slaty cleavage, axial planar to these folds, is the characteristic $S_{1}$ foliation in these rocks.

Cross-sections of the Stirling belt (Fig. 3), although somewhat speculative in areas of poor inland exposure, suggest that the belt is dominated by kilometre-scale antiformal and synformal structures; the antiformal structures are developed in areas of felsic rocks which were presumably formed as domes and other volcanic edifices, and the synformal structures are in areas underlain by pyroclastic and tuffaceous sedimentary rocks which presumably were deposited in one or more flanking troughs or aprons. This interpretation implies a strong primary paleogeographic or volcanic architectural component to the major structure prior to $F_{1}$ tectonic enhancement.

The mylonitic shear zones trend essentially parallel to the strike of the surrounding rocks and are more commonly developed on the southeastern side of the belt, within about 5 $\mathrm{km}$ of the L'Archeveque - Mira Bay fault system. Late $\left(F_{2}\right)$ chevron folds and kinks, plunging steeply east or west, appear to be restricted to the well-foliated rocks of these shear zones. Some carbonate occurrences appear to have provided loci for high strain in the shear zones as they typically form lenses of fine-grained, siliceous dolomitic marble within quartz-carbonate-talc/sericite mylonitic schist. The best example occurs in the footwall side of the ore zone of the Mindamar mine at Stirling, but other occurrences are located along strike southwest from Stirling within rhyolite porphyry and rhyolitic tuff (Fig. 2). In the absence of associated siltstone-chert laminites, such carbonate lenses may represent intensely carbonatized alteration zones.

The various large plutonic bodies of the Chisholm Brook Suite are essentially unfoliated. However, the Grand River leucogranite and the similar Capelin Cove and Point Michaud plutons of the Coastal belt, which flank the L'Archeveque Mira Bay fault system, all show evidence of strong cataclastic to mylonitic deformation.

The northeast-trending L'Archeveque - Mira Bay fault system, within and against which Upper Hadrynian to Lower Cambrian clastic rocks are preserved, dominates the area, and effectively separates the Coastal and Stirling belts. Parallel faults to the east and west contribute to the troughs east and west of Stirling within which more of these clastic rocks are preserved. The configuration of these down-faulted clastic basins suggests that they may be pull-apart basins formed by left-lateral strike-slip movement of the northeast-trending fault system. Transverse faults striking southeast and south to south-southeast appear to have post-dated the northeasttrending faults, having offset segments of these, as well as various rock units, toward the north and south; this is especially evident in coastal exposures between Point Michaud and $L$ 'Archeveque.

\section{Environment of Deposition of the Stirling Group}

In general, volcanic rocks of the Stirling Group do not show convincing evidence as to whether their deposition was subaerial or subaqueous. Although the mafic flows apparently lack pillow structures, subaqueous deposition cannot be precluded as the flows could be largely sheet flows formed at high discharge rates (Cas, 1992). They also commonly grade into breccias which show textural features resembling those of autoclastic flow breccias and possibly also of hyaloclastites formed by quench fragmentation. Locally (e.g., in coastal exposures near Point Michaud), they are interlayered with lenses of pyrite-rich, laminated siltstone which show evidence of intense soft-sediment deformation.

Pyroclastic rocks, which are predominantly lapilli tuffs and ash tuffs of intermediate composition, are tentatively interpreted to be mainly air-fall deposits. However, a subaqueous depositional component is also suggested because they show some textural evidence of reworking and are commonly interbedded with, and locally gradational into, tuffaceous litharenite and conglomerate. Intermediate to felsic tuffs in the hanging wall of the ore zone at the old Mindamar mine have been interpreted as subaqueous pyroclastic flows developed on the flank of a rhyolite dome (Miller, 1979). 
The volcaniclastic sedimentary rocks, with their abundance of sedimentary structures, show the best evidence of depositional environment. Graded bedding, basal scours and rip-up clasts in the tuffaceous litharenites indicate that deposition was via subaqueous mass flow. Furthermore, rarity of current bedding and ripple marks, and the virtual absence of wave and current cross lamination in the associated laminites, indicate that deposition occurred at depths below wave base.

As the tuffaceous sedimentary unit along the southeastem margin of the belt is in general finer grained, thinner and less continuous than in the central part of the belt, it is interpreted to have been deposited in a more distal position in relation to the main clastic sediment source, perhaps as an apron around the rhyolite porphyry domes. The thick central unit, in contrast, was probably deposited in an adjacent trough which was apparently supplied axially from the northnortheast as the unit becomes increasingly conglomeratic in that direction.

The common occurrence in the laminated siltstones of parallel laminations and small-scale soft-sediment structures, and the association with materials such as chert and micritic dolostone, are indicative of deposition from turbiditic suspension and of precipitation in a low-energy, distal environment.

The dolostone layers consist of fine-grained ferroan dolomite or ankerite (containing up $15 \mathrm{wt}$. \% FeO), minor spar and vein calcite, and rare clastic grains of quartz. Such iron-rich carbonate is not typical of normal surficial dolomite, and it is possible that it represents primary precipitation from hydrothermal fluid; boiling of a hydrothermal fluid under relatively low pressure (i.e., shallow water) conditions could produce a $\mathrm{CO}_{2}$-rich vapour phase which would react with cold seawater at or near the sea-floor and precipitate carbonate which might explain the association of stratabound carbonate alteration zones and bedded carbonates with $\mathrm{Zn}$ $\mathrm{Pb}$-Cu massive sulphide mineralization (Franklin, 1986; Large, 1992).

The stratabound concentrations of fine-grained pyrite in laminated siltstone contain small amounts of $\mathrm{Cu}, \mathrm{Zn}$ and $\mathrm{Au}$ (Mosher, 1979; Macdonald, 1989; Barr et al., 1989, in press) which, in combination with their close spatial association with chert and ferroan carbonate laminites, is suggestive of localized volcanic exhalative contributions to the depositional basin, as exemplified on a larger scale by the Mindamar massive sulphide deposit. Occurrences of chert, ferroan carbonate, and pyrite-rich layers in laminated siltstone sequences can be traced intermittently along strike for several kilometres from Stirling and are also concentrated in the Point Michaud area (Fig. 2). Such exhalite facies are considered to be favourable horizons for exploration as they may closely underlie or even mark the stratigraphic position of any related massive sulphide deposits (Ridler, 1970; Large, 1992).

The high ratio of volcaniclastic to volcanic rocks in the Stirling Group, and the deposition and reworking of the volcaniclastic material, are characteristic of a volcanic-arc environment (Garcia, 1978). Thick accumulation of volcani- clastic rocks in a trough adjacent to volcanic centres suggests that the arc setting may have been modified by block faulting or incipient rifting to form an intra-arc basin (Dickinson, 1974; Miller, 1989).

\section{Discussion}

Keppie (1979), Dostal et al. (1990), and Keppie and Dostal (1991) included volcanic and volcaniclastic rocks of the Stirling belt in the Fourchu Group (sensu lato), together with rocks of the Coastal belt to the southeast and the East Bay Hills to the northwest. They assumed that all three belts are of essentially the same Late Precambrian age, and also that there have been no major structural displacements between them. Using volcanic geochemistry, they devised a model for their coeval development in a broad ensialic magmatic arc above a subduction zone dipping toward the present-day northwest.

Mapping, supported by radiometric dating, in southeastern Cape Breton Island (Barr et al., 1988; Bevier et al., 1993; and this study) clearly demonstrate that there are significant lithological, depositional, structural, and age differences among these volcanic belts which cannot be adequately explained by the above model. In particular, the Stirling Group appears to be as much as $100 \mathrm{Ma}$ older than the volcanic and volcaniclastic rocks of the adjacent Coastal belt, and approximately $60 \mathrm{Ma}$ older than those of the East Bay Hills belt to the northwest (Fig. 1). Such an age span is unusually long for a single arc or arc complex to remain active which suggests a relatively complex amalgamation history for the three belts.

The only Late Precambrian units possibly common to both the Stirling and Coastal belts are granitic plutons which include the Capelin Cove pluton dated at ca. $574 \mathrm{Ma}$ (Bevier et al., 1993) and the Grand River pluton inferred on the basis of lithological similarity to be of the same age. In contrast, granitoid plutons common to both the Stirling and East Bay Hills belts have ages of ca. $620 \mathrm{Ma}$. These plutonic correlations suggest that amalgamation of the Stirling and East Bay Hills belts was achieved by $620 \mathrm{Ma}$, and amalgamation of the Stirling and Coastal belts by $574 \mathrm{Ma}$ (Fig. 4).

Although all belts share a cover of Upper Hadrynian to Lower Cambrian redbeds, and of Cambrian marine transgressive rocks, differences in thickness and lithology and offsets between the belts suggest that there have been structural displacements of both Late Precambrian - Early Cambrian and post-Cambrian ages. The cover rocks on the Stirling and Coastal belts are distinctly different prior to the deposition of the Lower Cambrian MacCodrum Formation (Barr et al., 1992, in press). The thick fault-bounded, coarse clastic sequence of the Kelvin Glen Group, which unconformably overlies the Stirling Group, may have accumulated as alluvial fan deposits in pull-apart basins formed by left-lateral strike-slip movements involving the L'Archeveque - Mira fault system (Fig. 4c). Strike-slip displacement at this time cannot be estimated, but widespread protomylonitic fabrics developed in the volcanic-plutonic infrastructure on both 


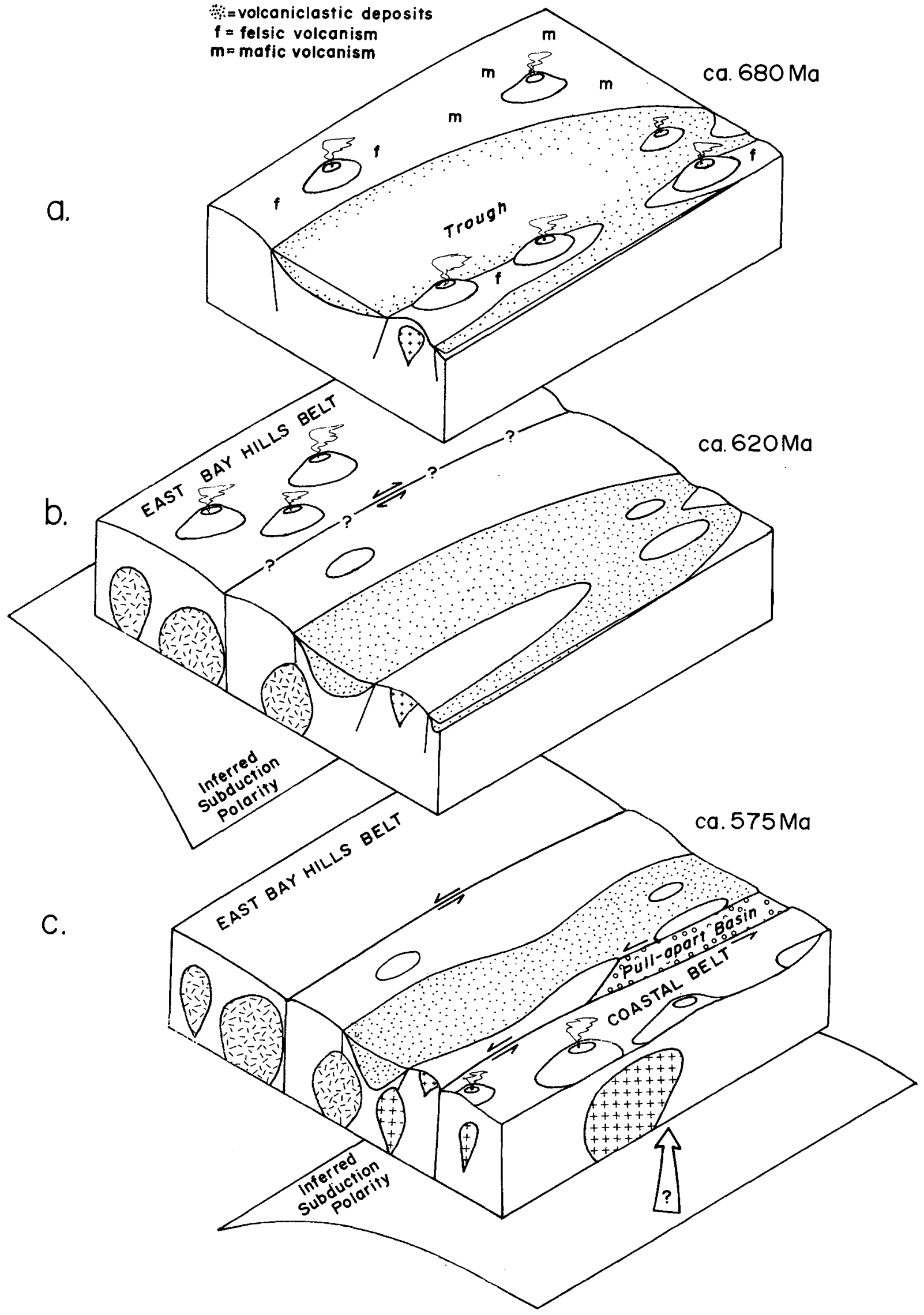

Fig. 4. Schematic diagram to illustrate the postulated magmatic and tectonic development of the Stirling belt and its incorporation into the Late Precambrian (Avalonian) composite terrane of southeastern Cape Breton Island. 
sides of the fault system are indicative of major ductile-brittle shearing. Post-Cambrian left-lateral displacement, which is suggested by apparent offset of Lower to Middle Cambrian strata across and within the L'Archeveque - Mira Bay fault system (Fig. 2), could have been as much as $30 \mathrm{~km}$.

In conclusion, depositional, structural and geochronological evidence suggest that the Stirling Group, which has some features of an intra-arc basin, represents an older, displaced block within the composite Mira (Avalon) terrane. Construction and assembly of this terrane was apparently accomplished over a time period of at least $100 \mathrm{Ma}$, possibly in an overall transpressive tectonic regime (Fig. 4). It is also suggested that this sequence of events was not unique to southeastern Cape Breton Island, as rocks similar in age to the Stirling Group occur in eastern Newfoundland juxtaposed with both older and younger volcanic-plutonic belts (O’Brien et al., 1992).

\section{ACKNOWLedgements}

Much of the work for this project was funded by the Geological Survey of Canada through the 1984-89 Canada Nova Scotia Mineral Development Agreement and the 199092 Canada - Nova Scotia Cooperation Agreement. We thank journal reviewers M. Doyon and S. Swinden for their helpful comments.

BARR, S.M. In press. Geochemistry and tectonic setting of Late Precambrian volcanic and plutonic rocks in southeastern Cape Breton Island, Nova Scotia. Canadian Journal of Earth Sciences.

BARR, S.M. and MACdonald, A.S. 1992. Devonian plutons in southeastern Cape Breton Island, Nova Scotia. Atlantic Geology, 28, pp. 101-113.

Barr, S.M., Macdonald, A.S., and White, C.E. 1988. The Fourchu Group and associated granitoid rocks, Coxheath Hills, East Bay Hills, and southwestern Stirling and Coastal belts, southeastern Cape Breton Island. Geological Survey of Canada, Open File 1759.

1989. The Fourchu Group and associated granitoid rocks, Stirling and Coastal belts, southeastern Cape Breton Island. Geological Survey of Canada, Open File 1988.

Barr, S.M., Dunnino, G.R., Raeside, R.P., and Jamieson, R.A. 1990. Contrasting U-Pb ages from plutons in the Bras d'Or and Mira terranes of Cape Breton Island, Nova Scotia. Canadian Journal of Earth Sciences, 27, pp. 1200-1208.

BarR, S.M., Macdonald, A.S., and White, C.E. 1992. Revision of upper Precambrian - Cambrian stratigraphy, southeastern Cape Breton Island, Nova Scotia. In Current Research, Part D, Geological Survey of Canada, Paper 92-1D, pp. 21-26.

BARr, S.M., White, C.E., and Macdonald, A.S. In press. Stratigraphy, tectonic setting, and geological history of Late Precambrian volcanic - sedimentary - plutonic belts in southeastern Cape Breton Island, Nova Scotia. Geological Survey of Canada, Bulletin 468.

Bevier, M.L., Barr, S.M., White, C.E., and Macdonald, A.S. 1993. U-Pb geochronological constraints on the volcanic evolution of the Mira (Avalon) terrane, southeastern Cape Breton Island, Nova Scotia. Canadian Journal of Earth Sci- ences, 30, pp. 1-10.

CAs, R.A.F. 1992. Submarine volcanism: eruption styles, products, and relevance to understanding the host-rock successions to volcanic-hosted massive sulfide deposits. Economic Geology, 87, pp. 511-541.

Dickinson, W.R. 1974. Sedimentation within and beside ancient and modern magmatic arcs. In Modern and ancient geosynclinal sedimentation. Edited by R.H. Dott Jr. and R.H. Shaver. Society of Economic Paleontologists and Mineralogists, Special Publication 19, pp. 230-239.

Dostal, J., Keppie, J.D., and MurPhy, J.B. 1990. Geochemistry of Late Proterozoic basaltic rocks from southeastern Cape Breton Island, Nova Scotia. Canadian Journal of Earth Sciences, 27, pp. 619-631.

Dostal, J., KepPIe, J.D., and Zhai, M. 1992. Geochemistry of mineralized and barren, Late Proterozoic felsic volcanic rocks in southeastern Cape Breton Island, Nova Scotia (Canada). Precambrian Research, 56, pp. 33-49.

Doyon, M. and VAN Wagoner, N.A. 1991. Geological environment of the Stirling volcanogenic massive sulphide deposit, southeastern Cape Breton Island. In Program and Summaries, Fifteenth Annual Open House and Review of Activities. Nova Scotia Department of Mines and Energy, Report 91-5, p. 47.

FrankLIN, J.M. 1986. Volcanic-associated massive sulphide deposits - an update. In Geology and Genesis of Mineral Deposits in Ireland. Edited by C.J. Andrew, R.W.A. Crowe, S. Finlay, W.M. Pennell and J.F. Pyne. Irish Association for Economic Geology, pp. 49-70.

Garcia, M.O. 1978. Criteria for the identification of ancient volcanic arcs. Earth-Science Reviews, 14, pp. 147-165.

Geological Survey of Canada. 1977. 1:25,000 Aetomagnetic Maps of Nova Scotia. Maps 20.285-287G, 20.294-296G and 20.302G.

KeppIE, J.D. 1979. Geological map of the Province of Nova Scotia. Nova Scotia Department of Mines and Energy, scale $1: 500,000$.

Keppie, J.D. and Dostal, J. 1991. Late Precambrian tectonic model for the Avalon terrane in Maritime Canada. Tectonics, 10. pp. 842-850.

Keppie, J.D., Dallmeyer, R.D., and Murphy, J.B. 1990. Tectonic implications of ${ }^{40} \mathrm{Ar} /{ }^{39} \mathrm{Ar}$ hornblende ages from Late Proterozoic-Cambrian plutons in the Avalon Composite Terrane, Nova Scotia, Canada. Geological Society of America Bulletin, 102, pp. 516-528.

LAROE, R.R. 1992. Australian volcanic-hosted massive sulphide deposits: features, styles, and genetic models. Economic Geology, 87, pp. 471-510.

Macdonald, A.S. 1989. Metallogenic studies, southeastern Cape Breton Island, Nova Scotia. Nova Scotia Department of Mines and Energy, Paper 89-1, 99 p.

MiLleR, C.K. 1979. The geological setting and environment of the ore deposition at the Mindamar Mine, Stirling, Richmond County, Nova Scotia. Unpublished M.Sc. thesis, Dalhousie University, Halifax, Nova Scotia, 223 p.

Miller, M.M. 1989. Intra-arc sedimentation and tectonism: Late Paleozoic evolution of the eastern Klamath terrane, California. Geological Society of America Bulletin, 101, pp. 170 187.

Mosher, G.Z. 1979. Report on geological, rock geochemical, airborne EM and magnetic surveys, Stirling, Richmond County, Nova Scotia. Cominco Limited for Nova Scotia Department 
of Mines and Energy. Assessment Report 11F/16B 07-O25(02).

O'Brien, S.J., Wardle, R.J., and Kino, A.F. 1983. The Avalon Zone: a Pan-African terrane in the Appalachian Orogen of Canada. Geological Journal, 18, pp. 195-222.

O'Brien, S.J., O'Driscoll, C.F., TuCker, R.D., and Dunning, G.R. 1992. Four-fold subdivision of the Late Precambrian magmatic record of the Avalon type area (east Newfoundland): nature and significance. Geological Association of Canada - Mineralogical Association of Canada Abstracts, 17. p. A85.

RIDLER, R.H. 1970. Relationship of mineralization to volcanic stratigraphy in the Kirkland-Larder Lakes area. Geological
Association of Canada, Proceedings 21, pp. 33-42.

SMITH, P.K. 1978. Geology of the Giant Lake area, southeastem Cape Breton Island, Nova Scotia. Nova Scotia Department of Mines and Energy, Paper 78-3, 21 p.

Swinden, S. and Hunt, P.A. 1991. A U.Pb age from the Connaigre Bay Group, southwestern Avalon Zone, Newfoundland: implications for regional correlations and metallogenesis. In Radiometric age and isotopic studies: Report 4. Geological Survey of Canada, Paper 90-2, pp. 3-10.

Weeks, F.J. 1954. Southeast Cape Breton Island, Nova Scotia. Geological Survey of Canada, Memoir 277, 112 p.

Williams, H. 1979. Appalachian orogen in Canada. Canadian Joumal of Earth Sciences, 16, pp. 792-807. 